\title{
Characteristics of Legal Entity Universities in Indonesia by the Output Achievements and Effectiveness of Performance
}

\author{
Doddy Tri Hardiyanto ${ }^{1}$, Hermanto Siregar $^{2} \&$ Hari Wijayanto $^{3}$ \\ ${ }^{1}$ School of Business, Bogor Agricultural University, Indonesia \\ ${ }^{2}$ Department of Economics, Faculty of Economics and Management, Bogor Agricultural University, Indonesia \\ ${ }^{3}$ Department of Statistics, Faculty of Mathematics and Natural Sciences, Bogor Agricultural University, \\ Indonesia \\ Correspondence: Doddy Tri Hardiyanto, School of Business, Bogor Agricultural University, Indonesia. E-mail: \\ doddy.th@gmail.com
}

Received: November 22, 2016

doi:10.5539/ass.v13n1p151

\author{
Accepted: December 6, 2016 Online Published: December 20, 2016 \\ URL: http://dx.doi.org/10.5539/ass.v13n1p151
}

\begin{abstract}
The aims of this study were to to find out about the characteristics of legal entity universities based on output indicators that achieved by the universities, to find out the characteristics of legal entity universities based on the performance affectivity achieved by the universities, and to analyse the relationship between budgeting and human resources quality on influencing the performance of legal entity universities. The method in this research is to use biplot analysis in view the characteristics of universities based on the achievement of outputs and effectiveness of its performance. As for the relationship between the budget and human resources of the universities performance using correlation analysis. The results of biplot analysis showed that the universities have different characteristics based on the number and effectiveness of the output achieved. Based on effectiveness, some universities have higher effective than other universities. Correlation analysis between the budget and human resources of the achievements of the output has a positive correlation with output achieved by the university.
\end{abstract}

Keywords: budgeting, effectiveness, legal entity, performance

\section{Introduction}

The increasing of the world globalization along with science and technology development took its own effect for the whole aspects of life, including in Higher Education. Globalization phenomena in the field of Higher Education is irresistible and has been processing in application of Higher Education in Indonesia at the present. Higher Education globalization is expected that the graduates of Higher Education in Indonesia could be compete in the global market, besides in the Free Trade of ASEAN (Association of Southeast Asian Nations) countries, so that the Higher Education in Indonesia is demanded to produce the graduates who have competitive ability with other countries. Refers to the international competitive ability, according to "World Economic Forum" in "The Global Competitiveness Report 2014-2015" that Indonesia is in the position 38 of 148 evaluated countries.

In the specified details of the evaluation indicator pillars, that one of the evaluated pillars is Higher Education and Training. The evaluation result of the Higher Education and Training pillar is Indonesia still at the position of 61. It should become consideration for all of the responsibility holder of Higher Education in government, Higher Education, and the society. By the Higher Education is expected that bale to create qualified human resources in the scientific aspect and social morality, in nationally or internationally. The research of Morote (2001) obtained that Higher Education and economic development have positive mutualism relationship, and also between Higher Education and manpower stages. According to Zhang (2006), Echevarria (2009), Keller (2010), and Shin (2012) explained that Higher Education has an important role in economic growth and territory development in globally context, especially for the developing countries. The importance of the role of universities in improving and strengthening the nation's economy, especially in the development of the stock exchange as suggested by Tanjung et al. (2014) that the need to develop more stock exchange corner programs in each university campus. One of the efforts to increase the quality of Higher Education is education autonomy, 
however according to Swaine (2012) that education autonomy is not the only way to solve the problems if it is not comparable with society development in the education surroundings which have tough moral characters to think step forward in the society. The same study on university autonomy carried out by Kreysing (2002) in Germany which raised the autonomy, accountability and organizational complexity in higher education. The study takes a case study in one of the universities in Germany, namely the University of Goettingen. The main aspect is a major issue in the study is the issue of financial autonomy and organization. It is against the backdrop of ideas manajerialism new era that believes in improving the competitiveness of the independent management policies should be strengthened college where the traditional university system in Germany the entire system is controlled by the state. Then Mitsopoulos and Pelegidis (2008) conducted a comparison of academic and financial autonomy of universities in seven European countries. The result is a positive correlation between the autonomy granted to academic efficiency, the number of scientific papers produced, and the number of publications are cited by other researchers. In connection with efforts to improve the competitiveness of universities according to Ambarita (2010) is with higher education by granting broad autonomy and authority to regulate itself.

In producing the qualified Higher Education, Indonesia government has arranged a regulation which organize system management of Higher Education particularly, and for that issue the Act Number 12 Year 2012 concerning Higher Education is arranged and published. On the Act, it is say that one of the ways to increase the Higher Education quality is by the autonomy of Higher Education. The implementation of Higher Eduacation autonomy is given selectively based on the evaluation performance by the Minister to state universities by applying financial management system of Public Service Entity (BLU) or arranging the legal entity universities. In particular for the legal entity universities, there are 11 state universities which have legal entity status at the present, although 4 state universities are still in the transition phase, namely Sepuluh November Institute of Technology, Diponegoro University, Hasanuddin University, and Padjadjaran University. And since 2015, other 7 state universities are getting the legal entity status and in 2014 they were passed through the transition process, they are Bogor Agricultural Institute, Bandung Institute of Technology, Airlangga University, Gadjah Mada University, University of Indonesia, Indonesia University of Education and University of Sumatera Utara.

The state universities which have legal entity status especially the seven universities above are considered as higher education which have better quality than other state universities because the legal entity universities is expected oncoming to the World Class University by our government. Refers to Altbach (2004), World Class University is a university which has prime level in the world with international standardization of excellent. The excellent are included excellent in research that admitted by international academic community by international publications, excellent in high quality and the best teaching staff in their own fields, excellent in academic liberty and intellectual enthusiasm, excellent in management, sufficient facility for academic activity, such as comprehensive library, sophisticated laboratory, and sufficient funding that support the learning and teaching process and also for research. And the other important thing is excellent in international cooperation, whether in academic program, research, and others. With the enthusiasm of Higher Education to attain the World Class University caused the increase of their quality indirectly. However, in fact, the levelling result that published by Ministry of Research, Technology, and Higher Education that some of the qualified legal entity of state universities do not get better level properly than the other evaluated universities. Afterwards, from the aspects of international publication indexed by Scopus, the problem is similar to the levelling result above. For instance, it is necessary to evaluate the performance effectively that attained by the legal entity universities and to monitor all the factors that related to its performance.

\subsection{Research Question}

Universities that have legal status, especially the seven state universities seen as universities that have better quality compared to other universities, state universities especially the legal entity shall be supported and encouraged by the Government towards World Class University. However, on the rating issued by Ministry of Research, Technology, and Higher Education, there is legal entity universities ranked still under the universities considered not as legal entity universities. Then when seen from international scientific articles indexed by Scopus encountered the same issue with the ranking results. Based on the above background, as for the formulation of the problem to be solved by doing this research are:

1) How the characteristics of legal entity universities based on the output indicators that achieved by the universities?

2) How the characteristics of legal entity universities based on the performance affectivity achieved by the universities? 
3) What is the relationship between budgeting and human resources quality on influencing the performance of legal entity universities?

\subsection{Research Objectives}

1) To find out about the characteristics of legal entity universities based on output indicators that achieved by the universities.

2) To find out the characteristics of legal entity universities based on the performance affectivity achieved by the universities.

3) To analyse the relationship between budgeting and human resources quality on influencing the performance of legal entity universities.

\section{Methods}

This research is a descriptive research that is a research for describing a particular condition based on the observed phenomena and indication. In this case, the descriptive concern about the performance result, processing, and output of universities in the seven legal entity universities above. This research used quantitative approach, where the approach is observe the characteristics of legal entity of universities based on performance affectivity that achieved towards the budgeting of legal entity universities, and also to find out the influence of budgeting and human resources quality for the performance of legal entity universities. This research was using some output indicators that are:

- Quantity of scientific articles indexed by Scopus

- Quantity of researches

- Quantity of public services

- Quantity of patent rights

- Quantity of majors in accreditation level A

- Quantity of majors in international accreditation

- Quantity of international students

- Quantity of international achievements

- Quantity of cooperation income

\subsection{Performance Affectivity}

Performance measurement is an essential part of the management control process, both public and private organizations. However, due to the characteristics of the different public sector organizations with the private sector, the emphasis and orientation measurement of performance was there a difference (Mahmudi, 2005). Performance measurement is particularly educational institutions has become a very important thing to be done by each of these institutions and government in conducting surveillance. This is consistent with the findings made by Yang (2015) in the country of Taiwan on the performance of educational institutions that have become a hot issue that arise where in the Asian countries a lot of autonomy to the universities so that universities move toward scientific management and emphasizing the performance of the organization effective and efficient. Asad and Mahfod (2015) argues that the measurement of performance management for universities as an important part in enhancing the effectiveness of the performance of academicians in universities. measuring the performance of the public sector is very important, one of the purposes assessment of performance in the public sector is the Knowing the level of achievement of the objectives of the organization, provides a means of learning employee, Improving the performance of the next period, giving consideration systematically into decision making reward and punishment, motivate employees, and creating public accountability.

According to Wibowo (2014), it is necessary to measure the performance to find out deviation of determined plans during the performance implementation, or whether the performance can be done in appropriate in the determined schedule, or whether the performance results have been achieved as expected appropriately. To carry out the measurement, it is needed the ability to measure performance so the presence of performance standardization is necessary. The performance evaluation can be held to the real and measurable performance. One of the performance standardization is by trending performance measures. Trending performance measures showed how the performance trend all the time, that comparing with the activities, results, or achievements, and baseline standardization that have been determined before. This performance standardization showed that the trending during certain period to the baseline, it can be increase or decrease are varied. 
In the relationship of performance measurement in universities then if it seen from the achieved output in certain years compared with the achieved input, in this research the accepted input by universities is the accepted budget of universities from the government and other education income (Donation of Education Establishment from Students (SPP)). The measurement of performance affectivity is described as follows:

\section{Performance $=\quad$ the achieved output in year $\mathrm{t}$}

\subsection{Biplot Analysis}

University budget in year $\mathrm{t}$

According to Gabriel (1971) biplot is a method uses in multivariate analysis to describe the element of line and column matrix in one graphic. Biplot analysis is a method to extend the visual evaluation graphically from data $\mathrm{X}$ matrix in a plot by combine the $\mathrm{X}$ matrix line vector that describing the objects with vector representing the $\mathrm{X}$ matrix column that describing the variable. Biplot analysis is based on the Singular Value Decomposition of a matrix. Singular Value Decomposition of a matrix is a basic theorem that uses in matrix calculation. The using of SVD because it is more efficient in computerized to producing the main and second of component scores, and it give the additional understanding about main component.

There are some information of biplot (Matjjik \& Sumertajaya 2011), that are:

1) The proximity among objects

The proximity of location of two objects is interpreted as the similar characters of two objects. The closer of the location of two objects, the more similar of the characters that showed by the variables values.

2) Variable Variety

The length of variable vector is proportional to the variety of the variable. The longer the vectors of a variable, the higher the variety of the variable.

3) Relationship between variable

The value of angle cosine between two variable vectors are describing the correlation of two variables. The narrower of the angles that made between two variables, the more positive of the high correlation $(<90)$. If the angle is made in perpendicular shape then both of the correlation are low $(=90)$. While if the angle is obtuse then the correlation is negative ( $>90)$.

4) The variable value of an object

The position of the object in the same line with a vector variable is interpreted as the amount of the object in the same line with it. The closer the position of object with the line that appointed by a variable, the higher of the variable to the object. Meanwhile if the line of the objects are opposite each other, then the value is low.

According to Mattjik and Sumertajaya (2011), biplot is a method to make image in many dimension space become space in two dimensions. The reduction of dimension caused the decreasing of information in biplot. Biplot is able to give the information about $70 \%$ from the whole information is considered adequate. In this research, biplot method is using to analyze dimension and attribute of legal entity universities toward output indicators that achieved by legal entity universities based on the quantity of achievements or the affectivity.

\subsection{Correlation Analysis}

Correlation analysis is data analysing of research aimed to find out the capacity or the form of relationship line between two variables and the amount of influence that caused by the one variable (free variable) towards other variable (bound variable) (Siregar, 2014). If $(\mathrm{X}, \mathrm{Y})=\{(\mathrm{X} 1, \mathrm{Y} 1),(\mathrm{X} 2, \mathrm{Y} 2), \ldots,(\mathrm{Xn}, \mathrm{Yn})\}$ is pairing observation of measured $n$ model in measuring two variables $\mathrm{X}$ and $\mathrm{Y}$, correlation between measuring two variables $\mathrm{X}$ and $\mathrm{Y}$ is classified as:

$$
r=\frac{\sum\left(x_{i}-\bar{x}\right) \sum\left(y_{i}-\bar{y}\right)}{\sqrt{\sum\left(x_{i}-\bar{x}\right)^{2} \sum\left(y_{i}-\bar{y}\right)^{2}}}
$$

The correlation value $\mathrm{X}$ and $\mathrm{Y}$ in value of 0 showed that there was no correlation between them. The amount of the value of Variable $\mathrm{Y}$ is free, unbound with the amount of value of variable $\mathrm{X}$; as well as the value of variable $\mathrm{X}$ is free, unbound with the amount of the value of variable $\mathrm{Y}$. If the high value of variable $\mathrm{X}$ is associating with the high value of variable $\mathrm{Y}$, and the low value of variable $\mathrm{X}$ is associating with the low value of variable $\mathrm{Y}$, then $\mathrm{X}-\mathrm{Y}$ correlate positively and the correlation value is about 0 and 1 . If the high value of variable $\mathrm{X}$ is associating with the low value of variable $\mathrm{Y}$, and the low value of variable $\mathrm{X}$ is associating with the high value of variable $\mathrm{Y}$, 
then X-Y correlate negatively with the value of the correlation is between 0 and -1 . The higher correlation value of $\mathrm{X}-\mathrm{Y}$, then it is closer in the value of 1 or -1 , and the closer the attachment of value of variable $\mathrm{X}$ and variable $\mathrm{Y}$ (Saefudin, et al., 2009). This study used correlation analysis where the variable $\mathrm{X}$ is the percentage of Doctorate Degree Lecturers, the percentage of Professor Lecturers, Government Funding, and the Community Funding from Donation of Education Establishment from Students (SPP). Variables Y used in this study is an indicator of the performance achieved by legal entity universities, namely quantity of scientific articles indexed by Scopus, quantity of researches, quantity of public services, quantity of patent rights, quantity of majors in accreditation level A, quantity of majors in international accreditation, quantity of international students, quantity of international achievements, and quantity of cooperation income. The attachment level and correlation capacity can be seen in the Table 1 .

Table 1. Correlation Level and Relationship Capacity

\begin{tabular}{ccc}
\hline No & Correlation Value $(\mathrm{r})$ & Relationship Level \\
\hline 1 & $0,00-0,199$ & Very weak \\
2 & $0,20-0,399$ & Weak \\
3 & $0,40-0,599$ & Adequate \\
4 & $0,60-0,799$ & Strong \\
5 & $0,80-0,100$ & Very Strong \\
\hline
\end{tabular}

Source: Siregar (2014)

\section{Results and Discussion}

\subsection{Results}

Generally, universities have special characteristics which are the added values for them in community. The excellence in particular fields are become good marketing strategy to interest new students and cooperation with industry. Even so the legal entity universities that generally each university has its own special characteristics. By biplot method as shown on Figure 1, that it can be seen the characteristics of legal entity universities toward their total output that achieved.

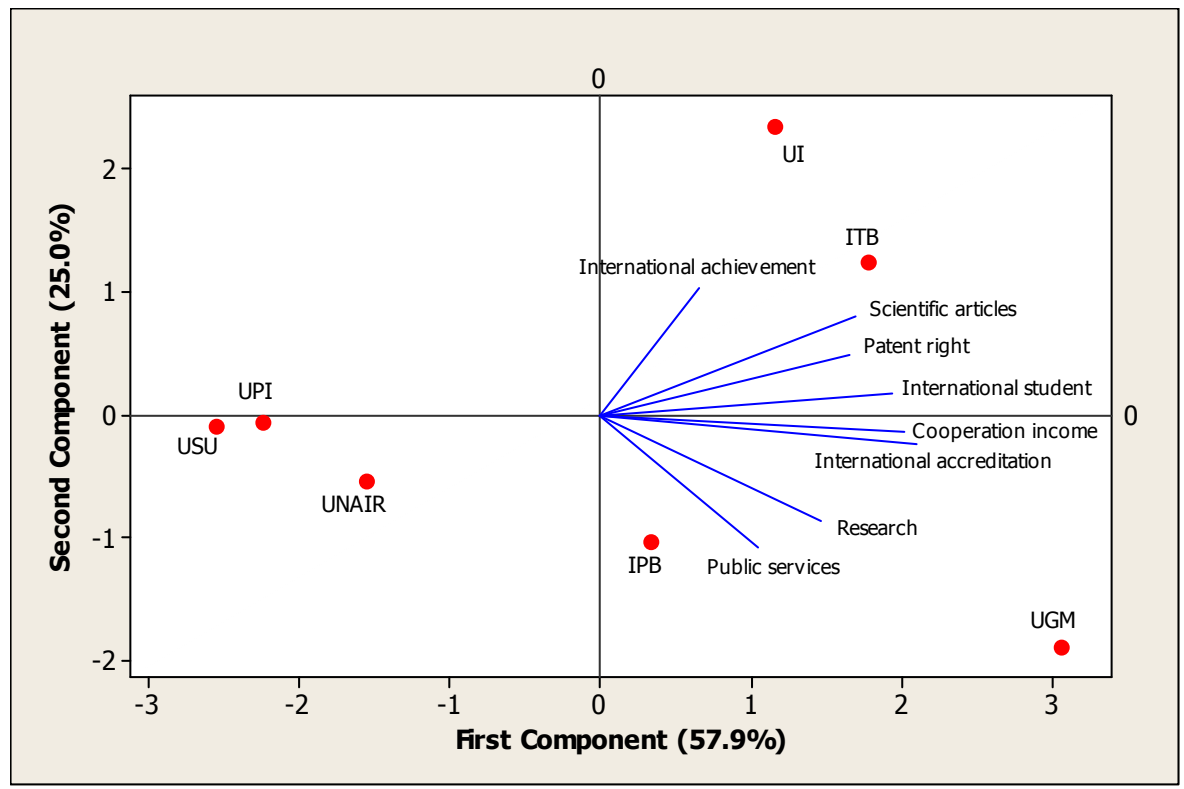

Figure 1. University output indicators by biplot method toward the seven legal entity of universities

In Figure 1, the variety of data can be explained in the amount of $82.9 \%$, with the first component is $57.9 \%$ and 
the second component is $25.0 \%$. Therefore, the resulted biplot of the data is quite good and represented the characteristics of the population as the criteria that suggested by (Matjjik \& Sumertajaya, 2011). The analysis results showed that relative proximity between legal entity universities and relative position of legal entity of universities toward output indicators that achieved by universities.

The affectiveness that conducted in this research is to observe the ratio between the achieved output and the total budget given by government and added with income from donation of education establishment in universities. Globally, the mapping of affectiveness level on each legal entity of universities can be described in biplot analysis in Figure 2.

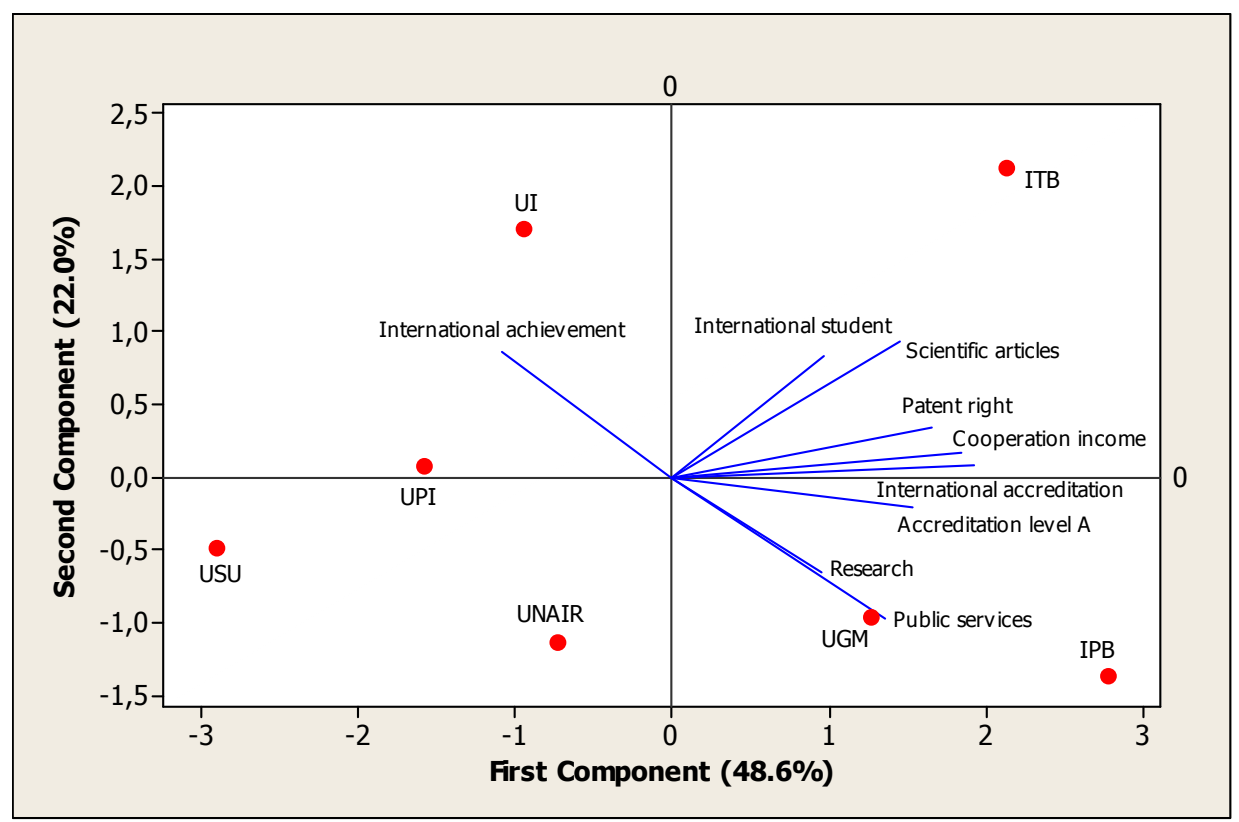

Figure 2. Biplot of performance affectivity towards total of government funding and SPP income

In the Figure 2, varied data can be explained in $70.6 \%$ with the first component is $48.6 \%$ and the second component is $22.0 \%$. Therefore, the resulted biplot on the data is quite good and could represented the characteristics of the population.

One of the main factors that considered having relation to output achievement of the universities is the amount of budget that obtained by legal entity universities. One of the biggest and continuity budgeting that accepted by universities are from the government and donation of education establishment from the students. Besides, human resources in universities are also have substantial relationship to the performance achievement. Identically, human resources in universities are lecturers and refers to the research of Apriani (2009) that there is an intense correlation between the competency of lecturers and the affective implementation of university's "Tridharma". The relationship between budgeting and human resources quality toward the performance is in the Table 2 .

Table 2. Correlation between budgeting and human resources quality toward the performance

\begin{tabular}{cccccc}
\hline & & $\begin{array}{c}\text { \%Doctorate } \\
\text { Degree } \\
\text { Lecturers }\end{array}$ & $\begin{array}{c}\text { \%Professor } \\
\text { Lecturers }\end{array}$ & $\begin{array}{c}\text { Government } \\
\text { Funding }\end{array}$ & $\begin{array}{c}\text { Community } \\
\text { Funding }\end{array}$ \\
\hline Accreditation Level A & Correlation & .546 & .632 & .109 & -.181 \\
& Sig. (2-tailed) & .043 & .015 & .711 & .535 \\
Patent Rights & Correlation & .678 & .462 & .095 & -.285 \\
& Sig. (2-tailed) & .008 & .096 & .748 & .324 \\
Publication indexed by & Correlation & .791 & .574 & .469 & .103 \\
scopus & Sig. (2-tailed) & .001 & .032 & .090 & .725 \\
& & & &
\end{tabular}




\begin{tabular}{|c|c|c|c|c|c|}
\hline Services & Correlation & .423 & .652 & .121 & -.153 \\
\hline & Sig. (2-tailed) & .132 & .012 & .681 & .601 \\
\hline \multirow[t]{2}{*}{ International Students } & Correlation & .437 & .324 & .774 & .514 \\
\hline & Sig. (2-tailed) & .118 & .258 & .001 & .060 \\
\hline \multirow[t]{2}{*}{ Researches } & Correlation & .122 & .242 & .503 & .134 \\
\hline & Sig. (2-tailed) & .678 & .405 & .067 & .649 \\
\hline \multirow[t]{2}{*}{ Cooperation } & Correlation & .916 & .609 & .338 & -.265 \\
\hline & Sig. (2-tailed) & .000 & .021 & .237 & .360 \\
\hline \multirow[t]{2}{*}{ International Accreditation } & Correlation & .738 & .833 & .708 & .314 \\
\hline & Sig. (2-tailed) & .003 & .000 & .005 & .274 \\
\hline \multirow[t]{2}{*}{ International Achievement } & Correlation & -.222 & -.310 & -.154 & .268 \\
\hline & Sig. (2-tailed) & .446 & .281 & .598 & .355 \\
\hline
\end{tabular}

\subsection{Discussion}

In the Figure 1, analysis results showed that relative proximity and relative position between legal entity universities toward output indicators that resulted by the universities. In the figure can be seen that:

1) The proximity between legal entity universities that having same characteristics relatively, they are Sumatera Utara University, Indonesia University of Education, and Airlangga University. The similar characteristics also can be seen in University of Indonesia and Bandung Institute of Technology. While Bogor Agricultural Institute and Gadjah Mada University are relatively have not adjacent with other universities.

2) In terms of the total achievement that resulted as a whole can be seen in Gadjah Mada University that having the highest achievement than other universities. The highest achievement are output of researches and community services. Meanwhile the lowest achievement is occurred in Sumatera Utara University, Indonesia University of Education, and Airlangga University. In Bogor Agricultural Institute, the highest achievement occurred for the community services, whereas in University of Indonesia and Bandung Institute of Technology the highest achievement are for the output of international achievement and publications indexed by Scopus.

3) The correlation in each output indicators that resulted by universities relatively have high correlation, unless for the output of international achievement that have not any correlation with the research output and community services because its show the angle of 90 degree or more. The highest correlation is shown by the smallest angle between the outputs, which is in the output of cooperation approval and the total of majors that nationally accredited minimum in level B. The small angle relatively also occurred for the output of the number of majors that nationally accredited minimum in level B and international accredited majors.

4) The length of resulted vectors showed that the variety levels of the resulted output achievement. The longest vectors occurred for output achievement of the number of international accredited majors. It is showed that there are universities which have many majors are in international accreditation, but in the other hand, many majors in other universities are not.

Meanwhile, in Figure 2 showed the mapping of legal entity universities toward output affectivity that achieved by the universities. The analysis results showed that the relative proximity and the relative position between legal entity universities toward the affectivity of output indicators that resulted by the universities. In the figure can be seen that:

1) The proximity between legal entity universities that relatively have same characteristics based on the affectivity that are Sumatera Utara University and Indonesia University of Education. The similarity of characteristics also can be seen in Gadjah Mada University and Bogor Agricultural Institute. Meanwhile, Bandung Institute of Technology, University of Indonesia and Airlangga University have not adjacent to other universities.

2) In terms of the overall output affectivity achievement, it can be seen in Bogor Agricultural Institute, Bandung Institute of Technology and Gadjah Mada University, its have the highest achievement between other universities. The low affectivity achievement relatively occurred in Sumatera Utara University and Indonesia 
University of Education. Generally, University of Indonesia and Airlangga University have level of the performance affectivity is as high as Bogor Agricultural Institute, Bandung Institute of Technology, and Gadjah Mada University, but University of Indonesia has the highest achievement of affectivity that occurred in the number of the output of achievement in international competition.

3) Correlation on each affectivity output that resulted by universities relatively has high correlation, unless in affectivity of the number of achievement in international competition that have not any correlation with the other output of affectivity because it showed angle in more than 90 degree. The highest correlation showed by the smallest angle between output of affectivity, which is on output of researches and community services. The small angle also occurred on the affectivity output of cooperation approval and the number of patent rights.

4) The length vector that resulted is shown by the variety level on achievement of the affectivity output. The longest vector is on the achievement of the number of majors in international accreditation. It showed that there are international accredited majors in the universities, however on the other side, there many universities even have not majors in international accreditation.

The relationship between budgeting and human resources quality toward the performance as can be seen on Table 2 (with alpha 10\%), it showed that the percentage of doctorate degree lecturers have positive relationship to the number of majors in accreditation level A (Sig. 0.043) in quite strong attachment that is in amount of 0.546, the number of patent rights (Sig. 0.008) in strong attachment that is in amount of 0.916, and the number of major in international accreditation (Sig. 0.003) in strong attachment in amount of 0.738 . The result is shown by the variable of the percentage of professor lecturers has positive relationship toward the number of majors in accreditation level A (Sig. 0.015) in strong attachment in amount of 0.632, the number of patent rights (Sig. 0.096) has quite strong attachment in amount of 0.574 , the number of community services (Sig. 0.012) has strong attachment in amount of 0.652 , the total of cooperation (Sig. 0.021) has strong attachment in amount of 0.609 , and the total of majors in international accreditation (Sig. 0.003) has very strong attachment in amount of 0.833 .

The results of correlation analysis for government funding that accepted by legal entity universities toward the performance have positive relationship to the numbe of publication (Sig. 0.090) has quite strong attachment that is 0.469 , the number of international students (Sig. 0.001) has strong attachment that is 0.774 , the number of researches (Sig. 0.067) has quite strong attachment in amount of 0.053 , and the number of majors in international accreditation (Sig. 0.005) has strong attachment in amount of 0.708 . Meanwhile, the analysis results of correlation to community funding that accepted by legal entity universities toward their performance is related positively only on the number of international students (Sig. 0.060) that has quite strong attachment in amount of 0.514

\section{Conclusion and Implications}

\subsection{Conclusion}

This research showed that each legal entity universities have different characteristics based on the output that achieved by universities. While, based on the achieved of output affectivity toward the accepted budget showed that there are legal entity universities namely Sumatera Utara University and Indonesia University of Education that their performance is relatively low compared to other legal entity universities. However, some legal entity universities namely Bogor Agricultural Institute, Bandung Institute of Technology and Gadjah Mada University showed good performance in general than other legal entity universities. Although University of Indonesia not showed good performance yet than other legal universities but it has higher affectivity level in international achievement than other legal entity universities.

The result of correlation analysis showed the positive relationship among the budgeting and quality of the lecturers toward the performance that achieved by legal entity universities. The attachment among variables is between quite strong up to strong among the variables.

\subsection{Implications}

Based on the analysed research results, it has been found some of output achievements and the affectivity are decrease in quite high value. It is necessary to become the attention for universities and government. The next below is the implication of research result that can be a consideration for government (the Ministry of Research, Technology, and Higher Education) and legal entity universities.

a. Government 
1) Carry out the intense evaluation towards the achievement of legal entity universities, not only in total aspect but also in affectivity aspect that related to the used budget.

2) The funding by the government has positive relationship to the resulted achievement of legal entity universities. Because of that, guarantee from the government on funding aid to legal entity universities is necessary.

3) The consolidation of regulation that protected the legal entity universities, so that program implementation of universities are not obstructed with law consequences that occurred.

b. Legal Entity Universities

1) Programs improvement to improve the resulted output achievement as responsibility to government and community, both in total aspect and affectivity aspect.

2) Focus on main competency of each university, so that the achieved results are more optimal.

3) Competency among lecturers has positive relationship to the resulted achievement by legal entity universities. So, the continuity of programs is necessary to develop the competency of lecturers.

\section{Acknowledgements}

The first author would like to thank to legal entity universities for allowing his using the data of universities and the scholarship for the study was provided by Ministry of Research, Technology, and Higher Education.

\section{References}

Altbach, P. (2004). World Costs and Benefits of World Class Universities. Washington: American Association of University Professors; Academe Online. January/February.

Ambarita, B. (2010). Improving the quality, relevance and competitiveness of universities facing the globalization. Jurnal Generasi Kampus, 1(3), 1-17.

Apriani, F. (2009). Influence of competence, motivation, and leadership the effectiveness of the work. Jurnal Ilmu Administrasi dan Organisasi, 16(1), 13-17.

Asad, M., \& Mahfod J. 2015. Performance management system in action, survey and questionnaire finding in higher education in Bahrain. International Journal of Business and Management, 10(8), 96-114. http://dx.doi.org/10.5539/ijbm.v10n8p96

Echevarria, D. (2009). The contribution of higher education to economic development in a globalized environment (Doctoral dissertation). Available from ProQuest Dissertation \& Theses.

Gabriel, K.R. (1971). The biplot graphic display of matrices with application to principal component analysis. Journal Biometrika, 58(3), 453-467. http://dx.doi.org/10.1093/biomet/58.3.453

Keller, B.M. (2010). Higher education and employment: an examination of how support for higher education can improve long-term economic performance (Doctoral dissertation). Available from ProQuest Dissertation $\&$ Theses.

Kreysing, M. (2002). Autonomy, accountability, and organizational complexity in higher education: the Goettingen model of university reform. Journal of Educational Administration, 40(6), 552-560. http://dx.doi.org/10.1108/09578230210446036

Mahmudi. (2005). Public Sector Performance Management. Yogyakarta; Akademi Manajemen Perusahaan YKPN.

Mattjik, A. A., \& Sumertajaya, I.M. (2011). Sidik Peubah Ganda dengan menggunakan SAS. Bogor; IPB Press.

Mitsopoulos, M., \& Pelegidis, T. (2008). Comparing the administrative and financial autonomy of higher education institutions in 7 EU countries. Journal Intereconomics, September/October, 282-288. DOI: 10. 1007/s10272-008-0262-y.

Morote, E. (2001). Relationship among higher education, economic growth and employment in the leading latin american emerging economies (Doctoral dissertation). Available from ProQuest Dissertation \& Theses.

Saefuddin, A., Notodiputro, K.A., Alamudi, A., \& Sadik, K. (2009). Statistika Dasar. Jakarta; PT Grasindo.

Shin, J.C. (2012). Higher education development in Korea: western university ideas, Confucian tradition, and economic development. Journal of Higher Education, 64, 59-72. http://dx.doi.org/10.1007/s10734-011-9480-5 
Siregar, S. (2014). Statistical Parametric For Quantitative Research: Equipped with Manual Calculation and Application SPSS Version 17. Jakarta; PT Bumi Aksara.

Swaine, L. (2012). The false right to autonomy in education. Journal Educational Theory, 62(1), 107-124. http://dx.doi.org/10.1111/j.1741-5446.2011.00.438.x.

Tanjung, H., Siregar, H., Sembel, R., \& Nurmalina, R. (2014). Factors affecting the volatility of the Jakarta composite index before and after the merger of two stock and bond markets in Indonesia. Asian Social Science, 10(22), 91-99. http://dx.doi.org/10.5539/ass.v10n22p91.

The Government of the Republic of Indonesia. (2012). Law of the Republic of Indonesia Number 12 Year 2012 on Higher Education. Jakarta: Secretariat of State.

Wibowo. (2014). Performance Management. Jakarta; Rajagrafindo Persada.

World Economic Forum. (2014). The Global Competitiveness Report 2014-2015. The World Economic Forum.

Yang, C. 2015. the effects of higher education's institutional organizational climate on performance satisfaction: perceptions of university faculty in Taiwan. Journal Internasional Business Research, 8(8), 103-117. http://dx.doi.org/10.5539/ibr.v8n8p103.

\section{Copyrights}

Copyright for this article is retained by the author(s), with first publication rights granted to the journal.

This is an open-access article distributed under the terms and conditions of the Creative Commons Attribution license (http://creativecommons.org/licenses/by/4.0/). 